THE CAMBRIDGE LAW JOURNAL 1970 


\section{THE \\ CAMBRIDGE LAW JOURNAL 1970}

EDITOR

C. J. HAMSON, M.A., LL.M.

Professor of Comparative Law

CAMBRIDGE

AT THE UNIVERSITY PRESS

FOR THE FACULTY OF LAW, UNIVERSITY OF CAMBRIDGE 1970 
Published by the Syndics of the Cambridge University Press Bentley House, P.O. Box 92, 200 Euston Road, London, N.W.1 American Branch: 32 East 57th Street, New York, N.Y. 10022 


\section{EDITORIAL COMMITTEE}

Professor C. J. Hamson, M.A., Ll.M., Chairman \& Treasurer Professor Glanville L. Williams, Q.C., LL.D., F.B.A.

D. W. BowetT, M.A., LL.B., Note Editor

R. W. M. DiAS, M.A., LL.B., Assistant Editor

R. N. Gooderson, M.A., Note Editor

J. C. Hall, M.A., LL.B., Note Editor

J. A. Jolowicz, M.A., Note Editor

L. S. SEALY, PH.D., Secretary

J. W. A. Thornely, M.A., Book Review Editor

D. G. T. WilliamS, M.A., Ll.B., Note Editor 


\section{CONTRIBUTORS OF ARTICLES}

BAXTER, C. Ultra vires and agency untwined . . . . . . . 280

COoTE, B. The effect of discharge by breach on exception clauses . . 221

DiAs, R. W. M. Temporal approach towards a new natural law . . 75

Heprle, B. A. Intention to create legal relations . • . . . 122

JACKSON, D. The judicial commonwealth . . . . . 257

Simpson, A. W. B. The early constitution of the Inns of Court . . 241

Williams, D. G. T. Protest and public order . . . . . . . 96

YALE, D. E. C. The delivery of a deed . . . . . . . . 52

\section{REPORT ANNOTATED}

Royal Commission on Local Government in England (Redcliffe-Maud Report) . . . . . . . . . . . . 12

\section{STATUTES ANNOTATED}

Administration of Justice Act 1969 . . . . . . . . . 15

Children and Young Persons Act 1969 . $\quad . \quad . \quad . \quad . \quad . \quad . \quad 17$

Divorce Reform Act 1969 . . . . . . . . . . . . 45

Employers' Liability (Compulsory Insurance) Act 1969 . . . . 25

Employer's Liability (Defective Equipment) Act 1969 . . . . 25 


\section{CASES ANNOTATED}

Breen $v$. Amalgamated Engineering Union

Bushell v. Faith . $\quad \cdot 41$

Calliope, The . . . . 199

Charrington $v$. Simons \& Co. Ltd. 201

Charterbridge Corporation $v$. Lloyds Bank and Another . 37

Gaiman v. National Association for Mental Health . . . 185

Ghani v. Jones . . . : 1

Gissing v. Gissing . . . 210

Gray v. Barr . . . . 194

Gulbenkian's Settlements (No. 2), $R e$

Hannam $v$. Bradford Corporation 188

Harbutt's Plasticine Ltd. v. Wayne Tank \& Pump Co. Ltd.

Hassan and Rasul v. The State

Jermyn Street Turkish Baths Ltd., $R e$

Leary $v$. National Union of Vehicle Builders . . . . 188

McPhail v. Doulton . . . 206

Matthews v. McLaren . . 30

Ministry of Housing and Local

Government v. Sharp . . 197

Morris, $R e$. . . . . . 204

Morris v. Crown Office . . 179
North Sea Continental Shelf

Cases . . 4

Owen v. Pook (H.M.I.T.): : 42

Parsons v. Burk, Vodanovich, Lochore and Kember . . 183

Pennant's Will Trusts, $R e$. . $\quad 33$

R. v. East Grinstead Justices, ex $p$. Doeve . . . . 12

R. v. Gaming Board for Great Britain, ex p. Benaim and Khaida . . . . . 177

R. v. Governor of Brixton Prison, ex p. Havlide . . 12

R. v. Horwood . . . . 23

R. v. Lipman . . . . 21

R. v. Sullivan . . . . 218

Rodwell, $R e$. . . . 213

Schmidt $v$. Secretary of State for Home Affairs . . . . 9

Tremain v. Pike . . . $\quad$. 28

Vacwell Engineering Co. Ltd. $v$. B.D.H. Chemicals Ltd. . . 30

Wieland v. Cyril Lord Carpets Ltd. . . . . 28

Wiseman v. Borneman . 19

Woollerton and Wilson Lid. v. Richard Costain Ltd. . . 201 


\section{BOOK REVIEWS}

Allott, A.: New Essays in African Law . . . . . . . 337

Amerasinghe, C. F.: State Responsibility for Injuries to Aliens . $\quad$. 143

BodDE, D. \& Morris, C.: Law in Imperial China, Exemplified by 190

Ch'ing Dynasty Cases (Translated from the Hsing-An Hui-Lan)

with Historical, Social and Juridical Commentaries . . .

Boussard, J.-L.: L'Enquête Publique en Angleterre: un moyen politicojuridique de contrôler l'Administration . . . . . . 344

Bracton on The Laws and Customs of England (translated by THORNE, S. E.)

Brinkhorst, L. J. \& Schermers, H. G.: Judicial Remedies in the European Communities. A Casebook . . . . . . 342

Calabresi, G.: The Costs of Accidents. A Legal and Economic Analysis 350

Chitty on Contracts (23rd ed., by Guest, A. G.) . . . . . 159

Coulson, N. J.: Conflicts and Tensions in Islamic Jurisprudence . 148

DAube, D.: Roman Law. Linguistic, Social and Philosophical Aspects 335

Derretr, J. D. M.: Religion, Law and the State in India . . . 150

Diamond, A. L. (Ed.): Instalment Credit . . . . . . . 333

Ehrmann, H. B.: The Case that will not Die. Commonwealth vs. Sacco and Vanzetti . . . . . . . . . . . 340

Gower, L. C. B.: The Principles of Modern Company Law (3rd ed.) . 162

Green, A. W.: Political Integration by Jurisprudence . . . . 342

Hahlo, H. R. \& KaHN, E.: The South African Legal System and its Background . . . . . . . . . .

Halderman, J. W. (Ed.): The Middle East Crisis: Test of International Law . . . . . . . . . . . .

Hanes, D. G.: The First British Workmen's Compensation Act 1897 .

HePple, B.: Race, Jobs and the Law in Britain . . . . .

Higgins, R.: United Nations Peacekeeping 1947-1967 Documents and Commentary. Volume I. The Middle East . . . . .

Hurnard, N. D.: The King's Pardon for Homicide before A.D. 1307323

JONES, G.: History of the Law of Charity 1532-1827 . . . . 322

Karlen, D., Sawer, G. \& Wise, E. M.: Anglo-American Criminal Justice 158

LEIGH, L. H.: The Criminal Liability of Corporations in English Law . 329

LEwIS, J. R.: Civil and Criminal Procedure . . . . . 155

MERRY, H. J.: Montesquieu's System of Natural Government . . $\quad 347$

MiLsom, S. F. C.: Historical Foundations of the Common Law . 318

Montrose, J. L.: Precedent in English Law and Other Essays (ed. by HANBURY, H. G.) . . . . . . . . . . .

Parker, A. \& Taylor, E. (Edd.): Modern Wills Precedents .. . 167

PArker, D. B. \& Mellows, A. R.: The Modern Law of Trusts . 164

Pollock, Sir F. \& Maitland, F. W.: The History of English Law (2nd ed. by Misom, S. F. C.) .

SMITH, D. D.: International Telecommunication Control: International Law and the Ordering of Satellite and other Forms of International Broadcasting 


\section{Book Reviews}

Smrth, J. C. \& Hogan, B.: Criminal Law (2nd ed.) . . . . . 156

Sweet \& Maxwell's Guide to the Estate Duty Statutes (edd. by WhEATCRoft, G. S. A. \& LeAKe, P. D.) . . . . . . 166

TAMblak, H. W.: Sinhala Laws and Customs . . . . . . 151

Veall, D.: The Popular Movement for Law Reform 1640-1660 . . 325

Woodfall's Law of Landlord and Tenant (27th ed. by BLundell, L. A. \& Wellings, V. G.) . . . . . . . . . 331

ZANDER, M.: Lawyers and the Public Interest: a Study in Restrictive Practices . . . . . . . . . . . . 153 


\title{
SUBJECT INDEX 1970
}

\author{
$\dagger$ indicates an article $\quad$ indicates a book review
}

Other references are to notes

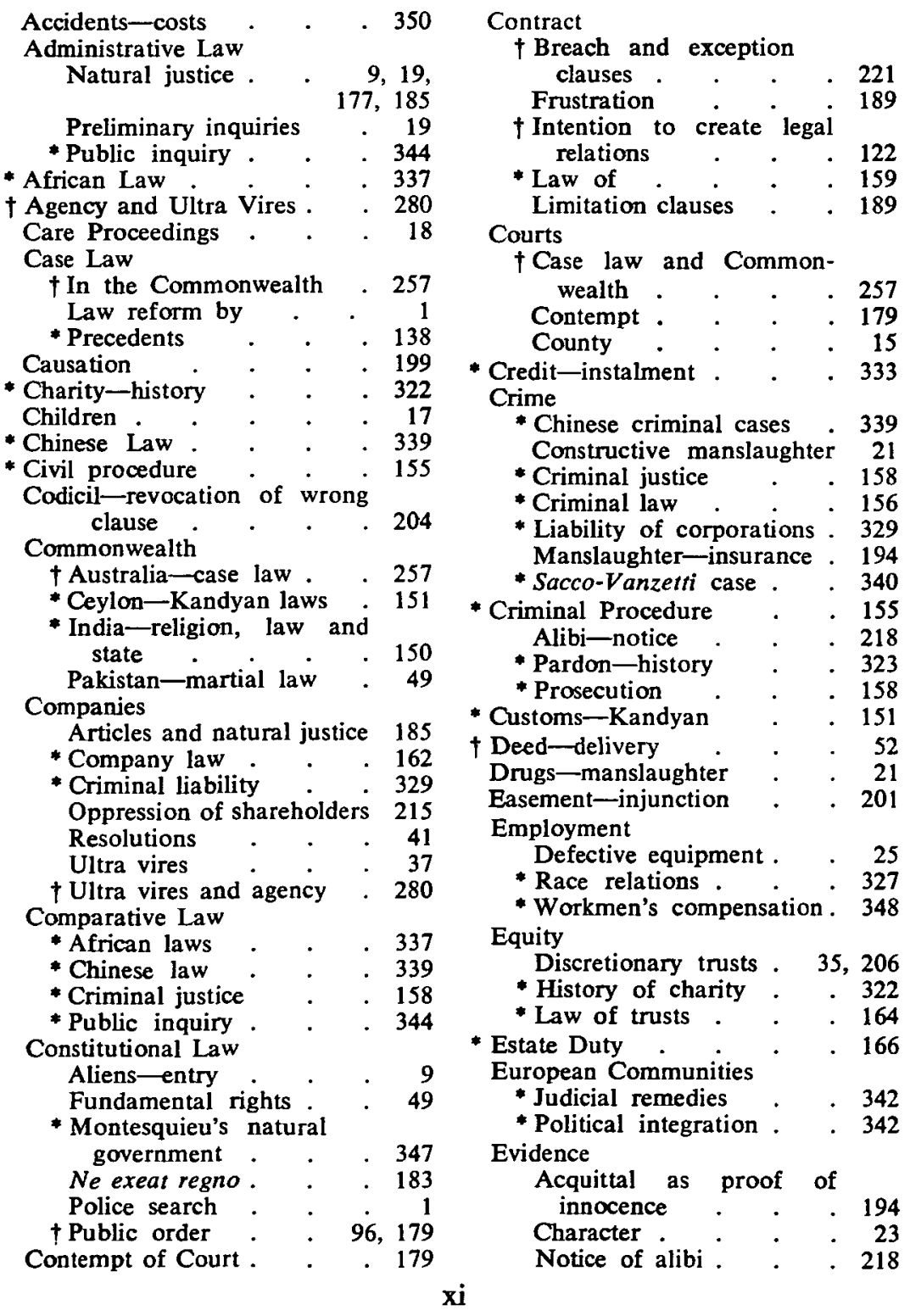


Family Law

Annulment of marriage . 213

Divorce

Matrimonial property . 210

Gaming-Gaming Board . 177

Injunction-suspension . . 201

$\dagger$ Inns of Court-history . . 241

Insurance-manslaughter - indemnity . . . . 194

International Law

* Continental shel

* Middle East crisis . . 345

* Peacekeeping . . . . 141

* State responsibility . . 143

* Telecommunications . . 145

* Islamic Law . . . . . 148

Jurisprudence

Grundnorm

* Islamic

$\dagger$ Natural law

* Precedent.

$\cdot \quad \cdot 138$

precedents

Law Reform

Accident Law . . . 350

By precedents . . . 1

* History . . . . 325

Legal History

* Bracton . . . . 314

* Charity . .. . . . 322

* Chinese law . . . 339

$\dagger$ Delivery of deed . $\quad 52$

* English law . . 139, 318

* Indian . . . . . 150

† Inns of Court . . . 241

* Law reform . . . 325

Ne exeat regno. . . 183

* Pardon . . . . 323

* Sinhala laws . . . 151

$\dagger$ Legal Profession-origin of call 241

Legal System

- Restrictive practices . . 153

* South African. . . 146

Local Government . . $\quad$. 12

Martial Law . . . . 49

Negligence

Breach of contract . . 189

Causation . . . 199
Negligence-cont.

Misstatements-third part-

ties . . . . 197

Remoteness . . . 28

Rescuer . . . . 30

Procedure

Appeal-“" leap-frogging" 16

* Civil and criminal . . 155

Public Order

Contempt of court . . 179

$\dagger$ Protest . . . . 96

Public Policy - manslaughter

-indemnity . . . 194

* Race Relations . . . . 327

* Religion and Law . . . 150

* Restrictive Practices - legal profession . . . 153

* Roman Law. . . . 335

* Roman-Dutch Law . . . 146

Schools-dismissal of teacher. 188

Settled Land . . . . 33

* South Africa-legal system . 146

Taxation

* Estate duty . . . . 166

Income tax . . . 42

Tenant for Life $\quad . \quad$. $\quad$. 33

Tort

Accidents . . . . 350

Assault . . . . 194

Causation . $\quad . \quad . \quad 199$

Injunction-trespass . . 201

Negligence $\quad$. 28, 30,

$189,197,199$

Trade Unions

† Contracts . . . . . 122

District Committee . . 187

Trusts

Natural justice . . . 188

Discretionary . . 35, 206

* Modern law . . . 164

University

Cambridge Law Society . 175 Wills

Codicil . . . . 204

Mentally disordered persons . . . . 17

* Precedents $\quad . \quad$. $\quad . \quad 167$ 
NOTES FOR CONTRIBUTORS

Communications concerning articles should be addressed to the Editor, Professor C. J. Hamson, 7 Cranmer Road, Cambridge; those concerning notes to Mr. J. C. Hall, St. John's College, Cambridge.

Books for review should be sent to the Cambridge Law Journal, Squire Law Library, The Old Schools, Cambridge.

A leaflet giving instructions about layout is available on application to the Editor. 


\section{THE \\ CAMBRIDGE \\ LAW JOURNAL}

\section{November 1970}

\section{CASE AND GOMMENT}

Administrative Law-Gaming Board Uproar in Court-Contempt No exeat regno Ambit of Natural Justice Frustration and Limitation Clauses Insurance-Manslaughter-Policy Negligent Statements-Third Party Loss

$\begin{array}{rrl} & 177 & \text { Causation-Consequential Damage } \\ & 179 & \text { Suspension of Injunction } \\ 183 & \text { Codicil-Revocation of Wrong Clause } \\ 177, & 185 & \text { Discretionary Trust-Objects } \\ & 189 & \text { Family Property-No Community } \\ & 194 & \text { Annulment of Marriage } \\ & & \text { Company Oppression of Shareholders } \\ & 197 & \text { Criminal Procedure-Alibi }\end{array}$

199 201 204 210 $2 \times 3$ 215

\section{ARTICLES}

The Effect of Discharge by Breach on Exception Clauses: B. cootE 221 The Early Constitution of the Inns of Court: A.W.B. smeson

The Judicial Commonwealth: D. Jackson

Ultra Vires and Agency Untwined: C. BAXTER

280

\section{BOOK REVIEWS}

BRACTON on The Laws and Customs of England. Volumes I and II (Trans. THORNR)

Mrsox: Historical Foundations of the Common Law

Jones: History of the Law of Charity 1532-1827

hURNARD: The King's Pardon for Homicide before A.D. 1307

venll: The Popular Movement for Law Reform 1640-1660

HePplaz: Race, Jobs and the Law in Britain (2nd ed.)

urron: The Criminal Liability of Corporations in English Law

woodpare's Landlord and Tenant. Volumes I and II (27th ed.)

DLAMOND (Ed.): Instalment Credit

DAUBz: Roman Law. Linguistic, Social and Philosophical Aspects
Allotr: New Essays in African Law

BODDE \& MORRE: Law in Imperial China, Exemplified by 190 Ch'ing Dynasty Cases

EHRManN: The Case that will not Die? 340 BRINKHORST \& sCHERMERs: Judicial

Remedies in the European

Communities. A Casebook

GREEN : Political Integration by Jurisprudence

Boussard: L'Enquete Publique en Angleterre

halderman (Ed.): The Middle East

Crisis: Test of International Law

MERRY : Montesquieu's System of Natural Government

Hanes: The First British Workmen's Compensation Act 1897

calanRrs: : The Costs of Accidents.

A Legal and Economic Analysis

\section{CAMBRIDGE UNIVERSITY PRESS}

Bentley House, 200 Euston Road, London, N.W.1

American Branch: 32 East 57th Street, New York, N.Y. 10022 